\title{
Retraction
}

\section{Retraction: Jeon, K.; et al. Laboratory Alignment Procedure for Improving Reproducibility of Tyre Wet Grip Measurement. World Electr. Veh. J. 2015, 7, 414-419}

\author{
World Electric Vehicle Association
}

check for

updates

Citation: World Electric Vehicle Association Retraction: Jeon, K.; et al. Laboratory Alignment Procedure for Improving Reproducibility of Tyre Wet Grip Measurement. World Electr. Veh. J. 2015, 7, 414-419. World Electr. Veh. J. 2021, 12, 51. https://doi.org/ 10.3390/wevj12010051

Received: 18 March 2021

Accepted: 22 March 2021

Published: 23 March 2021

Publisher's Note: MDPI stays neutral with regard to jurisdictional claims in published maps and institutional affiliations.

Copyright: (C) 2021 by the author. Licensee MDPI, Basel, Switzerland. This article is an open access article distributed under the terms and conditions of the Creative Commons Attribution (CC BY) license (https:// creativecommons.org/licenses/by/ $4.0 /)$.
1250 Eye Street, NW, Suite 902, Washington, DC 20005, USA; wevj@mdpi.com

The journal retracts the article, "Laboratory Alignment Procedure for Improving Reproducibility of Tyre Wet Grip Measurement" [1], cited above, due to redundant publication with "Laboratory Alignment Procedure for Improving Reproducibility of Tyre Wet Grip Measurement" by Jeon, K., et al. [2] in the International Journal of Automotive Technology, where the authors submitted their work in 2016 after submitting to 28th International Electric Vehicle Symposium Exhibition (EVS28) as a conference paper in 2015

The article is retracted from the World Electric Vehicle Journal and can henceforth be found under reference [2].

This retraction was approved by the Editor in Chief of the journal. The authors agreed to this retraction.

\section{References}

1. Jeon, K.; Yoo, Y.; Lee, J.; Jung, D.; Lim, S.; Park, S. Laboratory Alignment Procedure for Improving Reproducibility of Tyre Wet Grip Measurement. World Electr. Veh. J. 2015, 7, 414-419. [CrossRef]

2. Jeon, K.; Yoo, Y.; Lee, J.; Jung, D. Laboratory Alignment Procedure For Improving Reproducibility Of Tyre Wet Grip Measurement. Int. J. Automot. Technol. 2016, 17, 457-463. [CrossRef] 